\title{
ORDOVICIAN PALEOMAGNETISM OF EASTERN YUNNAN, CHINA
}

\author{
Wu Fang, Rob Van der Voo \\ Department of Geological Sciences, University of Michigan
}

Qizhong Liang

Yunnan Institute of Geological Sciences, Kunming

\begin{abstract}
Three magnetic components have been isolated in Ordovician formations of the Yangtze Paraplatform (South China Block). Two of these (Daqing A and Hongshiya B components) yield paleopoles that conform to the Carboniferous to Triassic segment of the apparent polar wander path for South China, and are therefore interpreted as remagnetizations. The third component (declination/inclination $=301^{\circ} \%+66^{\circ}, \mathrm{N}=5$ sites, $\mathbf{k}=21.4, \alpha_{95}=17^{\circ}$ ) passes the fold test and is interpreted as primary (late Early Ordovician). The paleopole, at $39^{\circ} \mathrm{S}, 236^{\circ} \mathrm{E}$, and the paleolatitude of $48^{\circ} \mathrm{S}$ support an Ordovician position of South China adjacent to Gondwana.
\end{abstract}

\section{Introduction}

The composite nature of Asia as an assemblage of crustal blocks has long been known [e.g., Argand, 1924; Mitchell, 1981; Li et al., 1982; Klimetz, 1983; Zhang et al., 1984], but the paleogeographic evolution of the individual tectonic elements, particularly for Paleozoic times, is very poorly documented Several recent papers favor the idea that many of the blocks were derived from Paleozoic Gondwanaland, with later northward movements as one after the other accreted to the Asian continent [e.g., Audley-Charles et al., 1988]. With the Siberian nucleus of Asia in more northerly Paleozoic paleolatitudes and Gondwana situated over the south pole, paleomagnetism is ideally suited as a technique to test Paleozoic paleogeographic models and the later northward drift of such blocks as Tarim, Indochina, North and South China.

In this paper we report on a paleomagnetic study of two formations: the Ordovician Daqing and Hongshiya formations, collected from the area near Kunming (Figure 1). Located at the southwestern end of the Yangtze Paraplatform (SCB), this area remained a stable platform experiencing only minor vertical movements for about 600 million years (late Precambrian to late Mesozoic), unlike other parts of the paraplatform where the Caledonian and Yanshanian (Jurassic) orogenies had profound effects. The section consists of shallow-water marine and epicontinental sequences, with a few regional disconformities but no major structural deformation and, hence, unconformities until the middle Tertiary. Earlier, we reported on Devonian paleomagnetic results from the same area [Fang et al., 1989], whereas Fang [1989] has described preliminary studies of the entire Ordovician and Silurian section, of which the two formations discussed here were the most promising.

Copyright 1990 by the American Geophysical Union.

Paper number 90GL00743

0094-8276/90/90GL-00743\$03.00

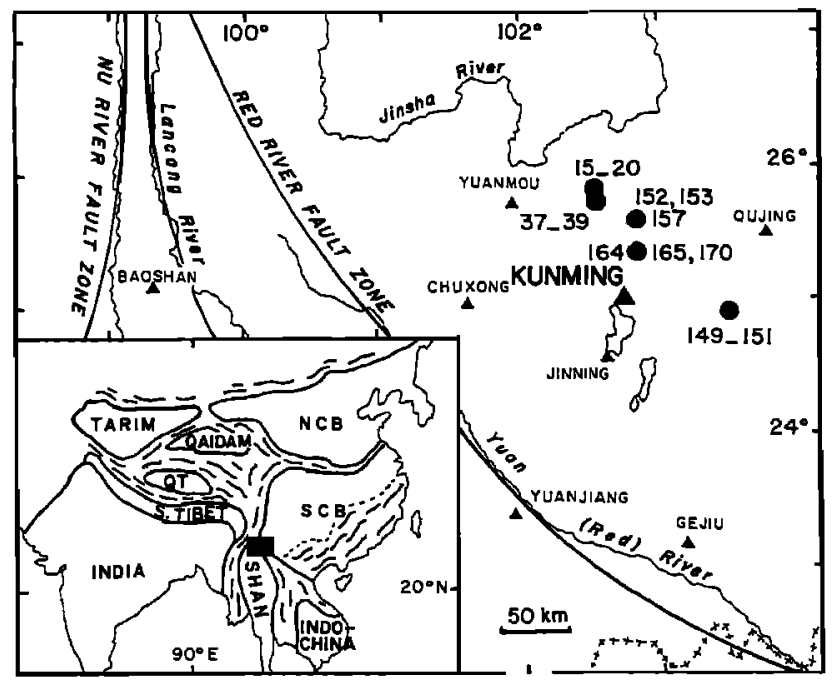

Fig. 1. Regional map of eastern Yunnan, with sampling sites indicated. The inset provides a sketch map of the tectonic elements of southeast Asia, modified from Li et al., [1982]. QT $=$ Qiangtang Block, Shan = Shan Thai Block, NCB and SCB $=$ North and South China Blocks, respectively.

\section{Geology and Paleomagnetic Results}

\section{Daqing Formation}

The Middle Ordovician fossiliferous Daqing Formation is composed of $220 \mathrm{~m}$ of thick-bedded gray dolomitic limestones that are gently tilted eastward with dips less than $20^{\circ}$ where sampled. The stratigraphic and geological setting of the Ordovician formations is described by Liang et al. [1984]. Severe weathering of outcrops at other localities prevented us from sampling for a fold test. Sampling was carried out stratigraphically over at least $70 \mathrm{~m}$ of section at less than $1-\mathrm{m}$ intervals in order to recognize reversals.

NRM intensities range from 0.2 to $1 \mathrm{~mA} / \mathrm{m}$, and all samples reveal similar behavior during demagnetization (Figure 2a,b). At low temperatures, a northerly and downward magnetization component is removed with a direction parallel to the presentday field, followed by linear decay to the origin of a northeasterly magnetization (A component). Sample and sitemean directions are shown in Figure 2c-e (see also Table 1).

The blocking temperatures (Figure 2a,b) and rapid Isothermal Remanent Magnetization acquisition [Fang, 1989] suggest that the magnetization in these carbonates is carried by magnetite. 

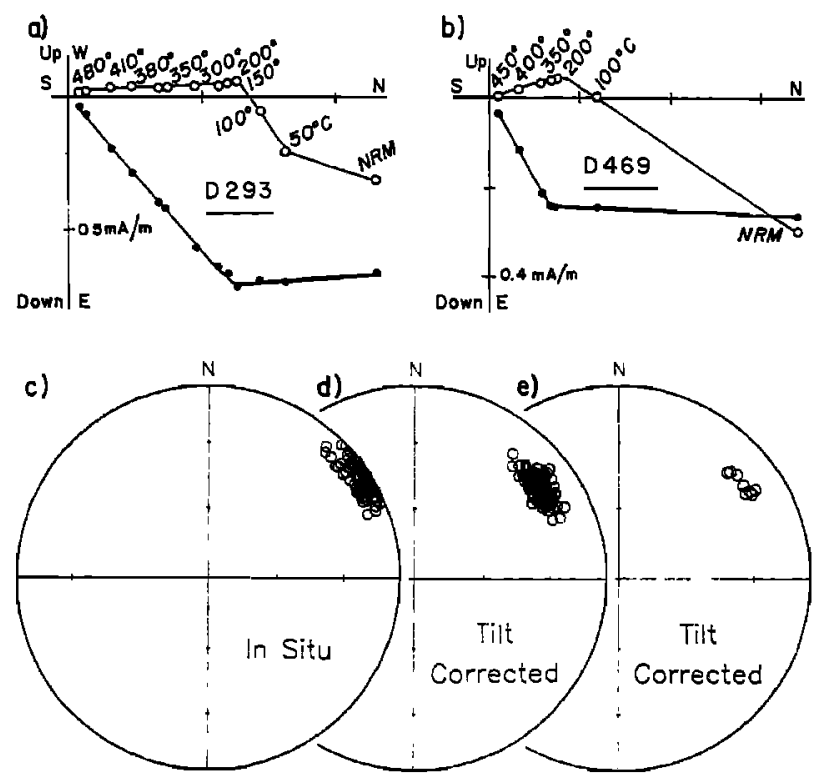

Fig.2. Orthogonal vector demagnetization diagrams [Zijderveld, 1967] of representative samples from the Daqing Formation (a,b) before tilt correction. Full (open) symbols represent endpoints of the magnetization vector projected onto the horizontal (vertical) plane. (c-e) Equal-area projections of characteristic sample directions (A component) before tilt correction (c), after tilt correction (d), and site-mean directions after tilt correction (e). Full (open) symbols represent lower (upper) hemisphere directions.

\section{Hongshiya Formation}

This late Early Ordovician formation directly underlies the Daqing carbonates, and consists of about $240 \mathrm{~m}$ of purple, green to yellow-brown alternating beds of sandstones, mudstones and shales. The formation is well-dated, in part on the basis of the trilobites Taihungshania migueli (Bergeron) and T. brevica Sun. The beds are tilted in different directions with moderate dips, so that a fold test is possible.

NRM intensities range from 1 to $20 \mathrm{~mA} / \mathrm{m}$. Demagnetizations reveal a variety of directions: (1) a presentday field direction often as an overprint on other directions, (2) a shallow northeasterly upward direction in only three samples from site 37, not unlike the Daqing A component, (3) a southwesterly intermediate upward direction (B component) in three sites, and (4) a steep northwesterly downward direction (C component) in five sites (Table 1). Orthogonal demagnetization diagrams are presented in Figure 3a-c for the C component; Fang [1989] has presented demagnetization diagrams for the $B$ component, which we interpret as a remagnetization.

Blocking temperatures (Figure 3a-c) indicate that the $\mathrm{C}$ magnetization is carried by hematite. The $C$ component passes the fold test at the $95 \%$ confidence level [McElhinny, 1964] with a $\mathrm{k} 2 / \mathrm{k} 1$ ratio of 4.0 for $\mathrm{N}=5$ sites (Table 1 ). However, the folding is of Tertiary age, so that the resulting age constraints on the magnetization are not very helpful in deciding the primary nature of the remanence. The $B$ component also appears to pass the fold test, although it is based on only three sites (Table 1).

\section{Interpretation}

The two formations yield coherent magnetizations, i.e., components found in more than two sites, in three different areas of the stereonet: one direction is northeasterly and shallow up (Daqing A, Figure 2, and Hongshiya site 37; Table 1 ), the second is southwesterly and intermediate up (Hongshiya B; Table 1), and the third direction is northwesterly and steeply down (Hongshiya C, Figure $3 \mathrm{~d}-\mathrm{e}$ ). Each of these directions shows one polarity only, and both Hongshiya directions pass the fold test, but this has marginal relevance in so far as the age of magnetization is concerned.

TABLE 1. Summary of Paleomagnetic Results

\begin{tabular}{|c|c|c|c|c|c|c|c|c|c|c|}
\hline Site & $\begin{array}{l}\text { Strikel } \\
\text { Dip }\end{array}$ & $\mathrm{n} / \mathrm{N}$ & $\begin{array}{l}\text { Compo- } \\
\text { nent }\end{array}$ & $\begin{array}{c}\text { In situ } \\
\text { Decl/Incl }\end{array}$ & $\begin{array}{l}\text { Tilt corrected } \\
\text { Decl/Incl }\end{array}$ & $\mathbf{k} 2$ & $\alpha_{95}$ & $\mathrm{k} 2 / \mathrm{kl}$ & $\begin{array}{l}\text { Range } \\
\left({ }^{\circ} \mathrm{C}\right)\end{array}$ & $\begin{array}{c}\text { Paleopole } \\
\text { (Lat., E-Long) }\end{array}$ \\
\hline $\begin{array}{l}\text { Midd } \\
15 \\
16 \\
17 \\
18 \\
19 \\
20 \\
38 \\
39 \\
\text { Mean }\end{array}$ & $\begin{array}{c}\text { Ordovician } \\
349 / 16 \\
\text { o/13 } \\
5 / 15 \\
343 / 19 \\
9 / 19 \\
34413 \\
347 / 23 \\
346 / 14 \\
\text { Daqing A }\end{array}$ & $\begin{array}{c}\text { Deqing } \\
8 / 8 \\
23 / 23 \\
6 / 8 \\
7 / 7 \\
33 / 33 \\
14 / 14 \\
7 / 7 \\
5 / 5 \\
8 / 8\end{array}$ & $\begin{array}{c}\text { Formation } \\
\text { A } \\
\text { A } \\
\text { A } \\
\text { A } \\
\text { A } \\
\text { A } \\
\text { A } \\
\text { A } \\
\text { A }\end{array}$ & $\begin{array}{ll}55.6 / & -5.3 \\
59.0 / & -5.0 \\
59.3 / & -9.7 \\
49.4 / & -1.9 \\
58.9 / & -5.2 \\
49.4 / & -1.9 \\
48.4 / & -1.7 \\
48.0 / & -8.6 \\
54.6 / & -5.5\end{array}$ & $\begin{array}{l}53.6 /-19.7 \\
57.1 /-15.8 \\
56.0 /-21.5 \\
48.0 /-19.2 \\
56.1 /-19.5 \\
48.0 /-19.2 \\
46.0 /-21.7 \\
46.2 /-20.9 \\
52.7 /-19.9\end{array}$ & $\begin{array}{l}355 \\
223 \\
153 \\
605 \\
202 \\
343 \\
742 \\
249 \\
246\end{array}$ & $\begin{array}{l}2.6 \\
1.8 \\
4.8 \\
1.6 \\
1.6 \\
1.9 \\
2.2 \\
4.9 \\
3.5\end{array}$ & 1.35 & $\begin{array}{l}300-510 \\
300-510 \\
300-480 \\
300-510 \\
300-510 \\
300-510 \\
300-480 \\
300-510\end{array}$ & $27.4 \mathrm{~N}, 220.8$ \\
\hline $\begin{array}{l}\text { upper } \\
37 \\
149 \\
150 \\
151 \\
152 \\
153 \\
157 \\
164 \\
165 \\
170 \\
\text { Form }\end{array}$ & $\begin{array}{c}\text { Lower Ordo } \\
209 / 35 \\
355 / 30 \\
1 / 30 \\
14 / 30 \\
67 / 35 \\
70 / 15 \\
3 / 19 \\
199 / 51 \\
196 / 33 \\
111 / 15 \\
\text { tion Means }\end{array}$ & $\begin{array}{c}\text { vician } H \\
3 / 11 \\
2 / 7 \\
7 / 7 \\
8 / 8 \\
6 / 6 \\
5 / 5 \\
6 / 6 \\
5 / 6 \\
7 / 7 \\
8 / 8 \\
\text { Honghir }\end{array}$ & $\begin{array}{c}\text { ongshiya } F \\
\text { A } \\
\text { pdf } \\
\text { B } \\
\text { B } \\
\text { C } \\
\text { C } \\
\text { C } \\
\text { C } \\
\text { C } \\
\text { B }\end{array}$ & $\begin{array}{r}\text { Formation } \\
26.3 /-13.7 \\
356.7 /+40.4 \\
191.7 /-40.7 \\
199.9 /-41.6 \\
325.4 /+30.9 \\
288.4 /+47.6 \\
288.5 /+62.6 \\
55.1 /+56.3 \\
139.2 /+77.8 \\
214.6 /-15.3\end{array}$ & $\begin{array}{r}34.8 /-12.8 \\
211.8 /-29.6 \\
221.8 /-32.1 \\
313.4 /+64.5 \\
272.0 /+55.3 \\
316.4 /+79.7 \\
334.5 /+51.0 \\
269.2 /+66.3 \\
215.4 /-30.1\end{array}$ & $\begin{array}{r}231 \\
- \\
35 \\
46 \\
54 \\
45 \\
16 \\
97 \\
222 \\
69\end{array}$ & $\begin{array}{r}7.9 \\
-5.6 \\
10.6 \\
8.3 \\
9.2 \\
11.6 \\
17.4 \\
7.8 \\
4.1 \\
14.5\end{array}$ & & $\begin{array}{l}200-480 \\
100-680 \\
350-640 \\
350-640 \\
300-680 \\
200-680 \\
200-680 \\
200-680 \\
200-680 \\
500-680\end{array}$ & \\
\hline & $\begin{array}{l}\text { Component } \\
\text { Component }\end{array}$ & $\begin{array}{l}3 / 10 \\
5 / 10\end{array}$ & B & $\begin{array}{l}203.4 /-33.1 \\
321.7 /+68.5\end{array}$ & $\begin{array}{l}216.3 /-30.7 \\
300.7 /+66.1\end{array}$ & $\begin{array}{r}318 \\
21\end{array}$ & $\begin{array}{r}6.9 \\
16.9\end{array}$ & $\begin{array}{r}16.04 \\
4.04\end{array}$ & & $\begin{array}{l}55.1 \mathrm{~N}, 200.4 \\
38.9 \mathrm{~S}, 235.7\end{array}$ \\
\hline
\end{tabular}

$\mathrm{n} / \mathrm{N}$ is the ratio of the number of entries (samples, sites) used in the statistical analysis to the number of entries sampled; pdf = present-day field; $k 2(\mathrm{kl})$ is the best estimate of the procision parameter after (before) tilt correction; Range gives the
blocking temperarures. 

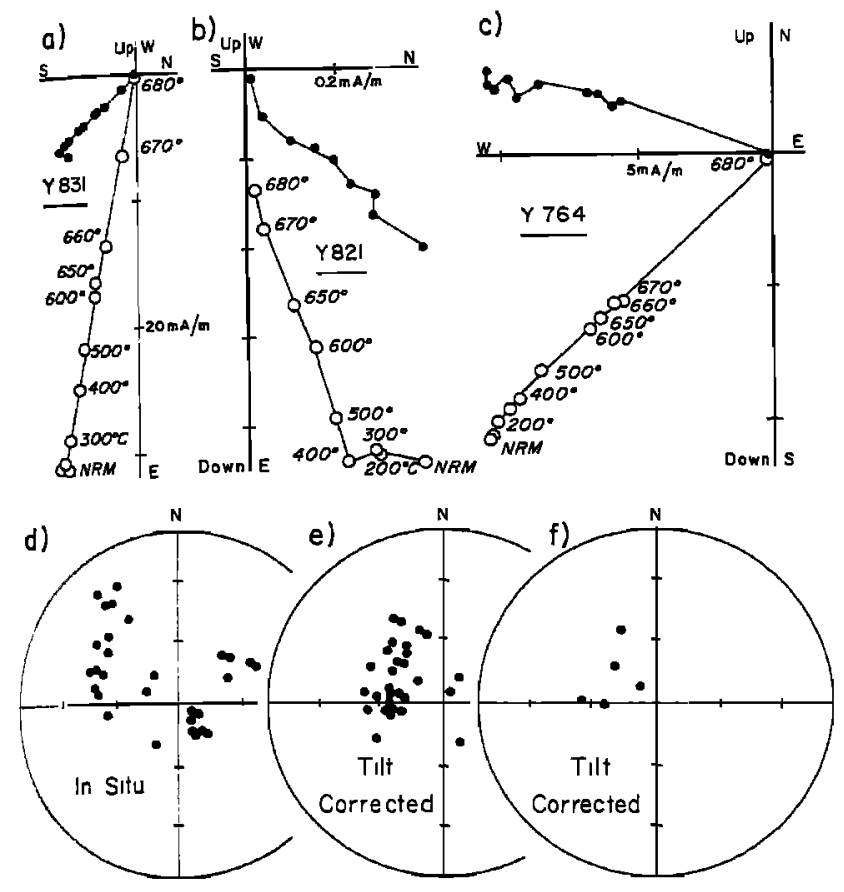

Fig. 3. Vector demagnetization diagrams as in Figure 2 of representative samples from the Hongshiya Formation (a-c) before tilt correction. (d-f) Equal area projections as in Figure $2 c-e$ of the Hongshiya $C$ component magnetizations.

Any of the three directions might be secondary, and given the large difference between the Hongshiya $B$ and $C$ components, one of them must be considered as a remagnetization.

In Figure 4, the pole positions calculated for the three magnetization components are plotted with the Phanerozoic apparent polar wander path for South China. The Daqing (A) and the Hongshiya $B$ poles fall on the apparent polar wander path segment for the Carboniferous to Middle Triassic. In the absence of any other conclusive evidence about the primary or secondary nature of the magnetizations, it seems prudent to conclude that the $A$ and $B$ poles both represent nemagnetizations. This is reminiscent of the paleomagnetic results obtained from early and middle Paleozoic carbonates of the North American platform which show widespread late Paleozoic remagnetizations [McCabe and Elmore, 1990]. Further support for the remagnetization model is found in the surprisingly tight grouping and uniform magnetization behavior of the Daqing A magnetization; similarly wellclustered results have been obtained from remagnetized New York State carbonates [e.g., McCabe et al., 1984].

The Hongshiya $\mathrm{C}$ pole does not resemble any Phanerozoic paleopoles thus far obtained, and we interpret it as representative of the Ordovician geomagnetic field in South China It is not clear whether the Hongshiya $C$ pole in Figure 4 is a north or a south pole, but the paleolatitude $\left(48.5^{\circ}\right)$ obtained from the inclinations is higher than the usually equatorial paleolatitudes obtained or inferred for most of the Paleozoic in paleogeographic analyses of South China [e.g., Nie and Lottes, 1989]. There are, however, independent indications for intermediate to high paleolatitudes for South China specifically for the earlier Ordovician [Scotese et al., 1979; Fortey and Morris, 1982], on the basis of sediment facies and paleobiogeography. The trilobite Neseuretus is

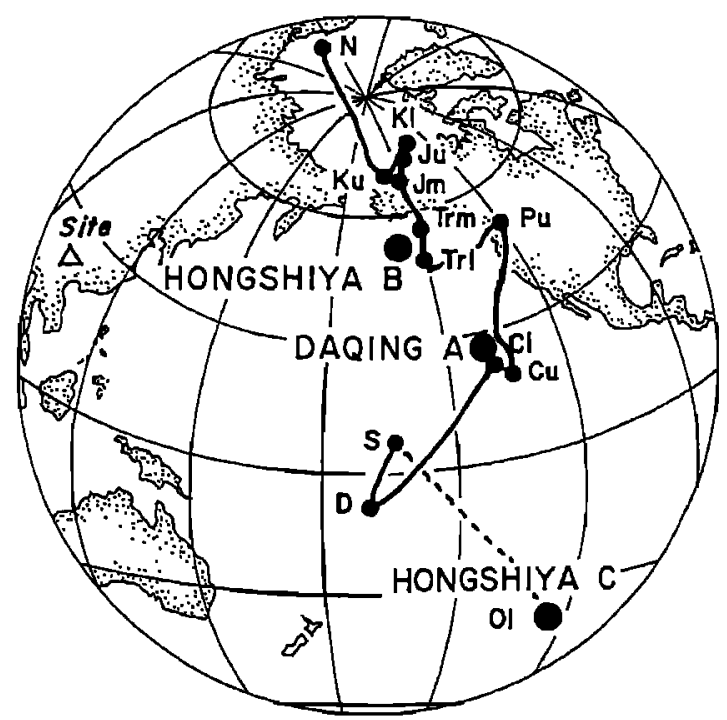

Fig. 4. Paleopoles for the Daqing A, Hongshiya $B$ and $C$ magnetizations from this study, together with the combined post-Cambrian apparent polar wander path for the South China Block [Lin et al., 1985; Fang et al., 1989]. Age abbreviations are: $\mathrm{N}=$ Neogene, $\mathrm{K}=$ Cretaceous and by first letters of the periods before that, $\mathrm{u}=$ upper, $\mathrm{m}=$ middle, and $\mathrm{l}=$ lower.

interpreted by Fortey and Morris [1982] as indicative of "the extent of relatively high-latitude areas in the (earlier) Ordovician and likely also to indicate close geographic proximity"; the occurrences of Neseuretus are plotted in Figure 5 (after Whittington and Hughes [1972] and Fortey and Morris [1982] in their paleolatitude framework). The assembly of Gondwana continents, southern Europe, and displaced terranes from eastern North America shown in this figure generally agrees with other paleogeographic models [e.g., Van der Voo, 1988], although the paleopole location is slightly more easterly in northern Africa than usually shown by

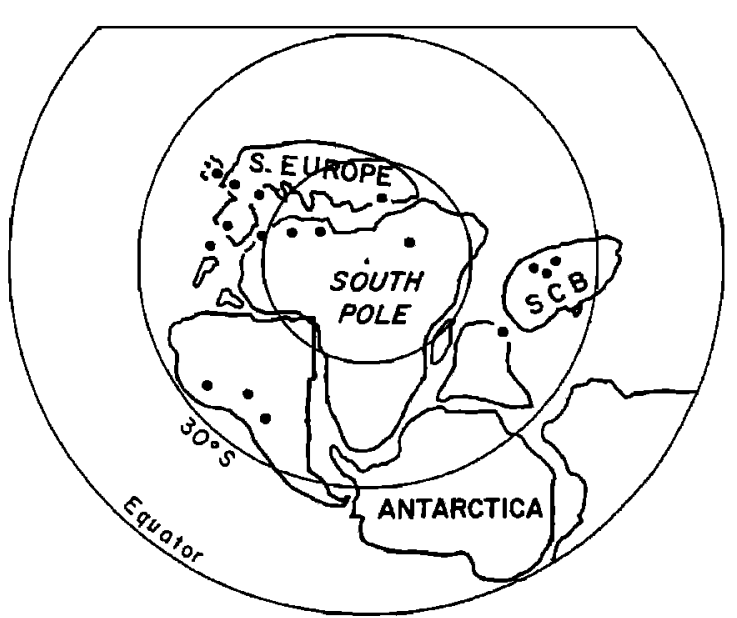

Fig. 5. Paleogeographic assembly of Gondwana and adjacent terranes (e.g., southern Europe) including the South China Block from this study, with occurrences of the trilobite Neseuretus [after Whittington and Hughes, 1972, and Fortey and Morris, 1982]. 
paleomagnetic syntheses. However, the locations of some Early to Middle Ordovician poles (e.g., Graafwater Formation of S. Africa and the Taylor Valley dikes of Antarctica) agree well with the mean pole location of Fortey and Morris [1982].

South China is positioned in Figure 5 according to our Hongshiya $\mathrm{C}$ pole, in a position very similar to that of Fortey and Morris [1982]. According to this position, the Hongshiya $C$ paleopole of Figure 4 would then be a northpole.

In conclusion, we interpret the Daqing $A$ and Hongshiya $B$ paleopoles from this study as based on secondary magnetizations of Late Paleozoic to Early Mesozoic age. The Hongshiya $\mathrm{C}$ paleopole is interpreted as primary, and its corresponding paleolatitude agrees well with previous paleogeographic syntheses based on trilobite distributions. The apparent polar wander path of the South China Block can now be extended from the Devonian and Silurian paleopoles [Fang et al., 1989; Opdyke et al., 1987] to the Early Ordovician location of Figure 4. Thus, the early Paleozoic paleogeographic position of the South China Block is likely to have been adjacent to Gondwana.

Acknowledgments. We thank Ben van der Pluijm and Zhongmin Wang for valuable comments on the manuscript. This research was supported by grants from the Geological Society of America (H. T. Steams Award to Wu Fang), Sigma $\mathrm{Xi}$, the Scott Tumer Fund, the Yunnan Geological Institute and the Division of Earth Sciences, the National Science Foundation, grant EAR 88-16772.

\section{References}

Argand, E., La tectonique de l'Asie, Proc. 13th Intern. Geol. Congress, Brussels, 171-372, 1924.

Audley-Charles, M. G., P. D. Ballantyne and R. Hall, Mesozoic-Cenozoic rift-drift sequence of Asian fragments from Gondwanaland, Tectonophysics, 155, 317-330, 1988.

Fang, Wu, Paleozoic paleomagnetism of the South China Block and the Shan Thai Block: The composite nature of Southeast Asia, Ph.D. Thesis, University of Michigan, Ann Arbor, 165 pp., 1989.

Fang, Wu, R. Van der Voo and Q. Z. Liang, Devonian paleomagnetism of Yunnan province across the Shan ThaiSouth China suture, Tectonics, 8, 939-952, 1989.

Fortey, R. A. and S. T. Morris, The Ordovician trilobite Neseuretus from Saudi Arabia, and the palaeogeography of the Neseuretus fauna related to Gondwanaland in the earlier Ordovician, Bull. Brit. Mus. Nat. Hist., 36, 63-75, 1982.

Klimetz, M. P., Speculations on the Mesozoic plate tectonic evolution of eastern China, Tectonics, 2, 139-166, 1983.

Li, C. Y., Q. Wang, X. Y. Liu and Y. Q. Tang, Explanatory notes to the tectonic map of Asia, Cartographic Publ. House of China, 49 pp, 1982.
Liang, Q. Z., and many others, Regional geologic survey in Kunming District, Documentary report of the Yunnan Geol. Bureau, Kunming, China, 1984.

Lin, J. L., M. Fuller and W. Y. Zhang, Preliminary Phanerozoic polar wander paths for the North and South China Blocks, Nature, 313, 444-449, 1985.

McCabe, C. and Elmore, R. D., The occurrence and origin of late Paleozoic remagnetization in the sedimentary rocks of North America, Rev. Geophys., 27, 471-494, 1990.

McCabe, C., R. Van der Voo and M. Ballard, Late Paleozoic remagnetization of the Trenton limestone, Geophys. Res. Lett., 11, 979-982, 1984.

McElhinny, M. W., Statistical significance of the fold test in paleomagnetism, Geophys. J. R. astr. Soc., 8, 338-340, 1964.

Mitchell, A. H. G., Phanerozoic plate boundaries in mainland southeast Asia, the Himalayas and Tibet, J. Geol. Soc. London, 138, 109-122, 1981.

Nie, S., and Lottes, A. L., Constraints on Paleozoic plate reconstructions of Chinese Blocks: paleoclimatic and paleomagnetic data compared (Abstract), Geol. Soc. America Abstr. with Progr., 21, p. A319, 1989.

Opdyke, N. D., K. N. Huang, G. Xu, W. Y. Zhang and D. V. Kent, Paleomagnetic results from the Silurian of the Yangtze Paraplatform, Tectonophysics, 139, 123-132, 1987.

Scotese, C. R., R. K. Bambach, C. Barton, R. Van der Vo and A. M. Ziegler, Paleozoic basemaps, J. Geol, 87, 217-277, 1979.

Van der Voo, R., Paleozoic paleogeography of North America, Gondwana and intervening displaced terranes: Comparisons of paleomagnetism with paleoclimatology and biogeographical patterns, Geol. Soc. America Bull., $100,311-324,1988$.

Whittington, H. B., and C. P. Hughes, Ordovician geography and faunal provinces, Phil. Trans. R. Soc. London, 263, 235-278, 1972.

Zhang, Z. M., J. G. Liu and R. G. Coleman, An outline of the plate tectonics of China, Geol. Soc. America Bull., 95, 295-312, 1984

Zijderveld, J. D. A., AC demagnetization of rocks: Analysis of results, in: Methods in Paleomagnetism, D. W. Collinson, K. M. Creer and S. K. Runcorn, editors, Elsevier, Amsterdam, pp. 254-286, 1967.

W. Fang and R.Van der Voo, Department of Geological Sciences, University of Michigan, 1006 C.C. Little Building, Ann Arbor, MI 48109-1063.

Q. Z. Liang, Yunnan Institute of Geological Sciences, Kunming, Yunnan, People's Republic of China.

(Received January 29, 1990;

revised March 23, 1990;

accepted March 24, 1990.) 